\title{
Socioeconomic status in Brazilian psychological research: II. socioeconomic status and parenting knowledge
}

\author{
Rodolfo de Castro Ribas $\mathbf{J r}$ \\ Universidade Federal do Rio de Janeiro \\ Maria Lucia Seidl de Moura \\ Universidade do Estado do Rio de Janeiro \\ Marc H. Bornstein \\ National Institute of Child Health and Human Development - USA
}

\begin{abstract}
Although studies of parenting cognitions and practices across cultures have increased systematically in the last years, research specifically on parents' knowledge of childrearing and child development remains very little frequent in non-U.S. settings. In Brazil this issue is still underresearched. This study addressed two main questions: What do Brazilian mothers know about childrearing and child development? How does this knowledge vary with their socioeconomic status and education in particular? A Brazilian version of the Knowledge of Infant Development Inventory (KIDI) was administered to a sample of 64 primiparous mothers, and data about the family's socioeconomic status were collected. Relations of SES and some of its components to parents' knowledge about childrearing and child development were then analyzed. The mean total correct score obtained by the Brazilian mothers on the KIDI was lower than the mean score obtained by the American mothers. There were no differences between KIDI scores obtained by mothers of boys and mothers of girls. Mothers' education was the best predictor of the KIDI. This study gives support to the view that differences in parenting knowledge are ascribable primarily to variation in educational attainment, a principal indicator of SES, and has implications for the development of parental educational programs.
\end{abstract}

Key words: parental knowledge; socioeconomic status; primiparous mothers

Resumo

Status socioeconômico na pesquisa psicológica brasileira: II. status socioeconômico e conhecimento parental. Embora os estudos sobre cognições e práticas parentais em diferentes culturas venham aumentando sistematicamente nos últimos anos, pesquisas sobre o conhecimento do desenvolvimento infantil e práticas parentais raramente vêm sendo conduzidas fora dos Estados Unidos. No Brasil praticamente não há literatura nessa área. Este estudo buscou responder a duas perguntas básicas: O que as mães brasileiras sabem sobre desenvolvimento infantil e as práticas parentais? Como este conhecimento sobre o desenvolvimento infantil e práticas parentais varia com o status socioeconômico e, em particular, com a educação das mães? Estudos vêm ressaltando a relevância do status socioeconômico para a análise de vários processos e produtos psicológicos. Porém, a relevância do status socioeconômico para o entendimento da cognições e práticas parentais ainda está sendo discutida. Uma versão em português do Knowledge of Infant Development Inventory (KIDI ) foi administrada em uma amostra de 64 mães primíparas, e dados sobre o status socioeconômico das família foram coletados. Foram analisadas as relações entre o status socioeconômico e alguns de seus componentes sobre o conhecimento do desenvolvimento infantil e de práticas parentais. Verificou-se que, em média, as mães brasileiras obtiveram um escore mais baixo no KIDI do que as mães norteamericanas. Não foram verificadas diferença entre mães de meninos e mães de meninas no KIDI. Todas as variáveis investigadas, exceto idade de mães e pais e status ocupacional das mães, mostraram correlação significativa com KIDI. A educação de mãe foi o melhor preditor dos escores no KIDI. Este estudo dá apoio à visão de que diferenças no conhecimento do desenvolvimento infantil e práticas parentais estão relacionadas principalmente ao nível educacional, um dos principais indicadores do status socioeconômico e têm implicações para o desenvolvimento de programas educacionais para os pais.

Palavras-chave: conhecimento parental; status socioeconômico; mães primíparas 
$\mathrm{S}$ ocioeconomic status (SES) has great importance in psychological research (Ribas, Seidl de Moura, Soares, Gomes, \& Bornstein, 2003). It is valuable not only for accurately characterizing the participant sample, but also for understanding the role of context in psychology. In this study, we investigated parents' knowledge of childrearing and child development and related that knowledge to parents' SES and to their educational level specifically.

Hoff, Laursen, and Tardif (2002) offered a meticulous discussion about relations between SES and parenting. Parents' cognitions have been frequently associated with SES (e.g., S. A. Miller, 1988). However, it is reasonable to speculate that such differences might be due solely or primarily to differences in educational attainment (Bornstein, Hahn, Suwalsky, \& Haynes, 2003; Hoff et al., 2002). In fact, most studies that have reported differences in parents' cognitions associated with SES have employed composite measures of SES and do not examine the effects of education separately (e.g., Harwood, Schoelmerich, Ventura-Cook, Schulze, \& Wilson, 1996; Hess, Kashiwagi, Azuma, Price, \& Dickson, 1980; MacPhee, 1981; Ninio, 1979). However, Benasich and Brooks-Gunn (1996) entered several sociodemographic variables (educational level, age, income, race/ethnicity) into a multiple linear regression predicting maternal attitudes and knowledge of childrearing and identified separate significant effects for education attainment and income.

In the present work we analyzed relations of SES and its components to mothers' knowledge about childrearing and child development. Although several investigations (e.g., MacPhee, 1981; Ninio, 1979) have associated knowledge about human development with SES (see also S. A. Miller, 1988), the sources of these associations are not sufficiently explained (Hoff et al., 2002).

Parents' knowledge of childrearing and child development is an emerging focus of parenting studies. Such knowledge includes understanding the diverse roles parents play in children's lives, how to care for children, and how children develop (Goodnow \& Collins, 1990; Sigel \& McGillicuddy-De Lisi, 2002). All of these aspects of parenting influence parents and children either directly or indirectly (Benasich \& Brooks-Gunn, 1996; Bornstein, 2002; Collins, Maccoby, Steinberg, Hetherington, \& Bornstein, 2000; Holden \& Buck, 2002; S.A. Miller, 1988; Murphy, 1992; Sigel \& McGillicuddy-De Lisi, 2002; Super \& Harkness, 1986). Studies of parenting knowledge investigate domains of knowledge and accuracy of knowledge, how parents of different statuses vary in their knowledge, and where and how parents acquire their knowledge.

Parenting knowledge covers many domains. The Knowledge of Infant Development Inventory (KIDI; MacPhee, 1981), the instrument used in the current study, assessed several areas of parenting knowledge. Parenting knowledge includes understanding child development - the basic needs, abilities, and accomplishments of children as they grow from birth through infancy into early childhood and beyond. Expectations about developmental norms and milestones - when a child is able to accomplish a particular developmental skill - affect parents' appraisals of their children's development and of child development per se. Parenting knowledge also includes basic information about children's health and the strategies recommended for maintaining health and coping effectively with illness. These cognitions guide parents in their decisions about how to maintain child health and the use of physician services (independent of the influence of signs and symptoms of illness), how to prevent illness, and when to seek care if children manifest symptoms (Hickson \& Clayton, 2002; Melamed, 2002). Parenting knowledge further includes understanding the various approaches appropriate to fulfilling the physical and biological, the socioemotional, and the cognitive needs of children as they develop (Bornstein, 1989, 2002; Goodnow \& Collins, 1990). Parenting practices include principles related to early experience, bidirectionality of social influences, atypical development, individual differences, instrumental beliefs about parenting strategies, management of the child through tuition or modeling, and the responsibilities of being a parent as well as statements about developmental processes, axioms and truisms about development, and descriptions of general abilities. The KIDI covers all these areas.

Because parents are the main caregivers of infants and young children, investigating the amount and types of knowledge parents possess about childrearing and child development is a necessary first step to increasing and improving the dissemination and utilization of parenting knowledge and thereby to improving children's quality of life. Parents' knowledge about childrearing and child development affects parents and their children's lives in many ways. The general state of knowledge that parents have constitutes a frame of reference out of which they interpret and make attributions about their children's behaviors. Knowledgeable parents have more realistic expectations and are more likely to behave in developmentally appropriate ways with their children (Grusec \& Goodnow, 1994), whereas parents who harbor unrealistic developmental expectations, or whose expectations are not informed by accurate knowledge of child development, experience greater stress as a result of mismatches between expectations and actual behaviors (Teti \& Gelfand, 1991).

Knowledge about childrearing and child development also affects parenting as it influences parents' everyday decisions about their children's care. Field, Widmayer, Stringer, and Igatoff (1980) found that high-risk mothers who had participated in a parent education program knew more about infants, had more realistic expectations of development, and also rated their infants as being less difficult in temperament. Knowledgeable parents approach interactions with their children with developmentally sensitive schemata in mind, including more accurate perceptions of children's capabilities as well as what their own role should be in moving children forward developmentally. By contrast, inaccurate parenting knowledge characterizes child maltreaters (Azar, 2002). 
Parenting knowledge also exerts direct effects on child development (C. L. Miller, 1988). Parents' knowledge about development, health, and safety influences the structure of the child's environment. For example, ratings of maternal accuracy on the KIDI accounted for 13-25\% of the variation on the Bayley Scales of Infant Development; infants of mothers with greater than average knowledge scored approximately 1 standard deviation higher on both the Mental Development Index (MDI) and the Psychomotor Development Index (PDI) than did infants of mothers who had less than average knowledge (Dichtelmiller, Meisels, Plunkett, \& Bozynski, 1992).

Parents from higher SES and those with more education appear to possess more formal knowledge about child development norms and theories and about optimal childrearing practices (Conrad, Gross, Fogg, \& Ruchala, 1992; MacPhee, 1981; Palacios, 1990; Parks \& Smeriglio, 1986). Lower-SES mothers are likely to have been poorer students themselves, and they refer to books or other written materials less readily as sources of information about child development and childrearing, whereas middle-SES women report that reading material is their primary source of information (Young, 1991). Middle-SES, more than lower-SES, parents also seek out and absorb expert advice about child development. Parents in higher socioeconomic strata change more flexibly and more rapidly in response to theory changes in parenting and development than parents in lower socioeconomic strata (Bronfenbrenner, 1958). Higher education is associated with more stimulating home learning environments (Parcel \& Menaghan, 1994).

Although studies of parenting cognitions and practices across cultures are multiplying in developmental science (e.g., Bornstein, 1991, 2001; Garcia-Coll \& Pachter, 2002; Harkness \& Super, 1995), research specifically on parents' knowledge of childrearing and child development remains relatively sparse in non-U.S. settings. The few studies that have been conducted have focused on three areas of parents' knowledge: specific health related practices, developmental milestones, and sources of parents' knowledge (e.g., Goodnow, Cashmore, Cotton, \& Knight, 1984; Impicciatore, Nannini, Pharm, Pandolfini, \& Bonati, 1998; Ninio, 1988; Tirosh, Mansour, Jaffe, \& Cohen, 1998). Pachter and Dworkin (1997), for example, administered the KIDI to mothers from minority (Puerto Rican, African American, West Indian/ Caribbean) and majority cultural groups in the United States asking for normal ages of attainment of typical developmental milestones during the first three years of life. Although all responses fit within a normative developmental range, significant differences emerged among ethnic groups for 9 of 25 developmental milestones.

These considerations of the importance of parenting knowledge to competence in parenting and to children's healthy and successful development, and the potential variation in parenting knowledge with culture, gave rise to two general questions that motivated this research. First, what do Brazilian mothers know about childrearing and child development? Second, how does mothers' knowledge about childrearing and child development vary with their socioeconomic status and education in particular?

\section{Method}

\section{Participants}

A total of 64 primiparous mothers participated in this study. The main inclusion criteria were as follows: (1) primiparous mothers, (2) aged 18 years and older, (3) with infants of 5 months of age and healthy at the time of the study, and (4) term at birth. A sampling scheme was also used in order to obtain a wide range of socioeconomic status participants. All mothers had intact families at the time of the study. Forty-seven percent $(n=30)$ of the families had two gainful employed householders, and 53\% had one gainful employed householder. Table 1 presents sociodemographic characteristics of the mothers and their spouses. There were no significant differences between mothers and their spouses in educational attainment. However, employed mothers $(n=$ 32) differed significantly from the spouses in occupational status ( $M=7.25, S D=1.68, M=5.55, S D=2.45$, respectively) and in age.

\section{Socioeconomic status}

Three indexes were employed to evaluate the SES: (1) the Hollingshead Four-Factor Index of Social Status (HI; Hollingshead, 1975); (2) the Revised Standard International Occupational Prestige Scale (SIOPS; Ganzeboom \& Treiman, 1996; Treiman, 1977); and (3) the International Socio-Economic Index of Occupational Status (ISEI; Ganzeboom, De Graaf \& Treiman, 1992; Ganzeboom \& Treiman, 1996). For households with only one gainfully employed householder, that gainfully employed householder determined the score of the household. For households with two gainfully employed householders, individual SES scores of the two householders were averaged to yield the household score. In a preliminary study involving 105 households, Bornstein, Seidl de Moura, and Ribas (2002) investigated the use of the three SES indexes (HI, SIOPS, and ISEI) in a Brazilian context. Their analyses revealed high zeroorder correlation coefficients among the three SES indexes, sharing $84.6 \%$ to $90.2 \%$ of their variance. These exploratory results give some support for the validity of the Hollingshead in Brazilian contexts. The results also shed some light on the interchangeability between indices. The 7-point scale of educational level and the 9-point scale of occupational status developed by Hollingshead (1975) were employed to evaluate education attainment and occupational status.

\section{Parenting Knowledge}

The Knowledge of Infant Development Inventory (KIDI; MacPhee, 1981; see also S. A. Miller, 1988) was used to assess knowledge of parenting practices and developmental processes, health and safety, and norms and milestones relevant to children from birth to 2 years of age. The first criterion established for the KIDI was to provide a broad coverage of information. The inventory contains 75 items, 48 
Table 1

Sociodemographic characteristics of the mothers and their spouses

\begin{tabular}{|c|c|c|c|c|c|c|}
\hline & \multicolumn{2}{|c|}{ Mother $(n=64)$} & \multicolumn{2}{|c|}{ Spouse $(n=64)$} & \multirow{2}{*}{$d f$} & \multirow{2}{*}{$t$} \\
\hline & $M$ & $S D$ & $M$ & $S D$ & & \\
\hline Education ${ }^{a}$ & 4.33 & $(1.88)$ & 4.20 & $(1.90)$ & 126 & .37 \\
\hline Age (years) & 26.52 & $(5.70)$ & 29.03 & $(5.90)$ & 126 & $2.44 *$ \\
\hline \multicolumn{7}{|l|}{ Education (\%) } \\
\hline Less than seventh grade & 15.63 & & 14.06 & & & \\
\hline Junior high school & 1.56 & & 6.25 & & & \\
\hline Partial high school & 10.94 & & 12.50 & & & \\
\hline High school graduate & 21.88 & & 20.31 & & & \\
\hline Partial college & 15.63 & & 18.75 & & & \\
\hline Standard college or graduation & 25.00 & & 15.63 & & & \\
\hline Post graduation & 9.38 & & 12.50 & & & . \\
\hline Occupation $b$ & 7.25 & $(1.68)$ & 5.55 & $(2.45)$ & 92 & $3.52 *$ \\
\hline $\mathrm{HI}^{\mathrm{c}}$ & 42.12 & $(15.88)$ & - & - & & \\
\hline SIOPS $^{\mathrm{d}}$ & 46.76 & $(13.87)$ & - & - & & \\
\hline ISEI $^{\mathrm{e}}$ & 51.83 & $(16.28)$ & - & - & & \\
\hline
\end{tabular}

${ }^{\mathrm{a}}$ Hollingshead 7-point education scale. ${ }^{\mathrm{b}}$ Hollingshead 9-point occupation scale. ${ }^{\mathrm{c} H o l l i n g s h e a d ~ F o u r-F a c t o r ~ I n d e x ~ o f ~}$ Social Status. ${ }^{\mathrm{d}}$ Standard International Occupational Prestige Scale. ${ }^{\mathrm{e}}$ International Socio-Economic Index of Occupational Status. ${ }^{*} p<.05 . M(S D)$

of which ask respondents to indicate whether they agree, disagree, or are unsure about a series of statements; for example, "Baby girls are fragile and sick more often, so they need to be treated more carefully than boys." An additional 20 items ask respondents to choose among four responses agree, younger, older, or unsure - in relation to statements about when a child should be able to achieve a particular milestone; for example: "Most infants are ready to be toilet trained by one year of age.” The remaining 7 items are either questions or sentence completions with five possible answers; for example: "Select the most appropriate game for a one-year-old: (a) stringing small beads, (b) cutting out shapes with scissors, (c) rolling a ball back and forth with an adult, (d) sorting things by shape and color, (e) not sure”. All items on the KIDI were worded so that they would be accessible to individuals with no more than a 6th grade education and so as to be free of sociocultural biases. The KIDI can also be divided in four subscales: (1) Norms and milestones, composed of 32 items that describe the typical infant's behavior at a given point in time; (2) Principles, composed of 17 statements about the developmental processes; (3)
Parenting, composed of 14 items related to instrumental beliefs about parenting strategies; and (4) Health and safety, composed of 12 items concerned with proper nutrition and health care, accident prevention, and the identification and treatment of common ailments (MacPhee, 1981, p. 10). The KIDI was originally standardized on four groups: college students, mothers, doctoral level psychologists, and pediatricians in the United States (MacPhee, 1981). The proportion of total items that were correct, the measure used in this study, was positively and monotonically related to the degree of practical and professional experience with children (mean proportion correct $=.62, .72, .86$, and .87, for college students, mothers, developmental psychologists, and pediatricians, respectively). Two-week test-retest stabilities for mothers $(N=58)$ ranged from .80 to .92 , and split-half reliabilities averaged .85. Among our sample, Chronbach's alpha was high (.81).

Several steps were taken to promote the validity and cultural appropriateness of the Brazilian form of the KIDI for we aimed to arrive at a translation that had "adapted" equivalence from a psychological perspective (van de Vijver 
\& Leung, 1997). The questionnaire, originally constructed and written in English, was first translated into Portuguese and then back translated by bilingual bicultural Brazilian natives using standard back-translation techniques. Professional psychologists or pediatricians next checked the translated instrument for preservation of meaning and cultural appropriateness. Then, professionals and bilingual mothers who were not participants in the study were interviewed regarding the cultural validity of items in the instrument. Finally, pilot testing was undertaken to ensure that the instrument was comprehensible and ethnographically valid (see Brislin, 1980, 1986; van de Vijver \& Leung, 1997).

\section{Results}

Prior to any analysis, distributions of the dependent variables were screened for normalcy, homogeneity of variance, and outliers. Because of outliers, data from 2 mothers were omitted. No transformations were required since no substantial violations of assumptions were detected.

The mean total correct score obtained by the Brazilian mothers on the KIDI, $M=.63, S D=.11$, was lower than the mean score obtained by the American mothers in MacPhee's (1981, Table 6) original study, $M=.72, S D=.12$. The mean total correct score on the KIDI obtained by the mothers of boys ( $n=31, M=.62, S D=.12$ ) did not differ from the mean total correct score on the KIDI obtained by the mothers of girls $(n=33, M=.63, S D=.10), t(62)=.34, n s$.
Table 2 presents zero-order correlations of all variables investigated in the study. As observed previously, the zeroorder correlation coefficients among the three SES indexes were high, ranging from .90 to .94; the three indexes overlapped substantially, sharing $81.0 \%$ to $88.4 \%$ of the variance.

All of the variables investigated, except mothers' and fathers' age and mothers' occupational status, correlated significantly with KIDI. Mothers' education showed the highest correlation with the KIDI. A stepwise multiple regression analysis was conducted, with the KIDI total score as dependent variable and father's education, father's occupation, and mother's education as independent variables. Mother's education was the best predictor of the KIDI, $R^{2}$ $($ adj $)=.20, F(1,61)=15.91, p<.001$. The other independent variables did not contribute to the percentage of variance explained, and they were excluded from the model.

A stepwise multiple regression analysis was also conducted for each of the four KIDI subscales. Father's education, father's occupation, and mother's education were the independent variables. Mother's education was the only predictor of the proportion of correct responses in three of the four subscales of the KIDI: Norms and milestones, $R^{2}$ $(\operatorname{adj})=.09, F_{(1,61)}=7.35, p<.01$; Principles, $R^{2}(\operatorname{adj})=.15$, $F_{(1,61)}=11.75, p<.001$; Parenting, $R^{2}$ (adj) $=.25, F_{(1,61)}=21.06$, $p<.001$. None of the independent variables predicted the proportion of correct responses in the Health and safety subscale.

Table 2

Zero-order correlations among the variables

\begin{tabular}{|c|c|c|c|c|c|c|c|c|c|c|}
\hline Variable & & 1 & 2 & 3 & 4 & 5 & 6 & 7 & 8 & 9 \\
\hline 1. Father's Education & $\mathrm{a}$ & - & & & & & . & & & \\
\hline 2. Father's Occupation & $\mathrm{b}$ & $.74 * *$ & - & & & & & & & \\
\hline 3. Fathe r's Age (years) & & $.42 * *$ & $.40^{* *}$ & - & & & & & & \\
\hline 4. Mother's Education & a & $.69 * *$ & $.71 * *$ & $.44 * *$ & - & & & & & \\
\hline 5. Mothe r's Occupation & $\mathrm{b}$ & $.62 * *$ & $.71 * *$ & .29 & $.74 * *$ & - & & & & \\
\hline 6. Mother's Age (years) & & $.41^{* *}$ & $.47 * *$ & $.63^{* *}$ & $.52 * *$ & $.40^{*}$ & - & & & \\
\hline 7. $\mathrm{HI}^{\mathrm{c}}$ & & $.82 * *$ & $.94 * *$ & $.44 * *$ & $.82 * *$ & $.90 * *$ & $.52 * *$ & - & & \\
\hline 8. SIOP $d$ & & $.67 * *$ & $.87 * *$ & $.34 * *$ & $.75 * *$ & $.85^{* *}$ & $.54 * *$ & $.89 * *$ & - & \\
\hline 9. ISEI ${ }^{\mathrm{e}}$ & & $.75^{* *}$ & $.89 * *$ & $.41 * *$ & $.78 * *$ & $.85^{* *}$ & $.49 * *$ & $.94 * *$ & $.90 * *$ & - \\
\hline 10. KIDI ${ }^{\mathrm{f}}$ & & $.35^{*}$ & $.34 * *$ & .07 & $.41 * *$ & .24 & .01 & $.36^{* *}$ & $.28 *$ & $.31^{*}$ \\
\hline
\end{tabular}

${ }^{\mathrm{a}}$ Hollingshead 7-point education scale. ${ }^{\mathrm{b}}$ Hollingshead 9-point occupation scale. ${ }^{\mathrm{c}}$ Hollingshead Four-Factor Index of Social Status scale. ${ }^{\mathrm{d}}$ Standard International Occupational Prestige Scale. ${ }^{\mathrm{e}}$ International Socio-Economic Index of Occupational Status. ${ }^{\mathrm{f}}$ Knowledge of the Infant Development Inventory. ${ }^{*} p<.05 ; * * p<.01$ 


\section{Discussion}

Parenting knowledge, that is, understanding patterns and processes of childrearing and child development, affects parenting in many ways. Insofar as more informed parents act and respond more positively, skillfully, and effectively in their childrearing activities and responsibilities, more knowledgeable parents should feel themselves to be more competent in their parenting role. Knowledge helps parents to develop more realistic expectations of their children and improves parents' self-perceptions (Goodnow \& Collins, 1990); more knowledgeable mothers interact with their children and behave in developmentally more appropriate ways with their children (Grusec \& Goodnow, 1994; Sanson \& Rothbart, 1995); and parenting knowledge facilitates parents' structuring their interactions with their children. It is also mothers' parenting that is most consistently associated with developmental outcomes in children.

In this study, we evaluated childrearing and child development knowledge in mothers in Brazil, and we assessed the relative contributions of SES and education to parenting knowledge. In Brazil, mothers of girls and mothers of boys scored the same in terms of their parenting knowledge. Mothers' level of education contributed uniquely to higher knowledge scores.

We found that mothers of young children are generally informed about child development principles and parenting practices, health and safety measures in childrearing, and normative milestones of child development. Because leaving a baby alone in a bathtub may put the child at risk for drowning, it is reassuring that the majority of parents (86\%) know to avoid this practice. Similarly, because immunizations are essential to maintaining health and preventing disease as early as the baby's first year of life, that most of mothers (94\%) report knowing this fact is also very positive.

At the same time, the data on proportion of incorrect answers force us to ask why Brazilian mothers got approximately $40 \%$ or more items on childrearing and child development incorrect? There appear to remain specific issues about which mothers are less well informed. For example, because the use of excessive bedding (such as soft pillows and blankets) is associated with higher incidence of SIDS, it is dismaying that just $40 \%$ of mothers answered this item correctly. The KIDI assessment was developed for children through 2 years so some knowledge might depend on experience, and our participants were all parents of 5month-olds. However, most questions in the KIDI are generic and general and do not rely on specific past memories of specific children.

Our findings about what mothers know have implications for children's well-being, as parenting knowledge provides an important context for understanding the nature of children and their development. Mothers' expectations about general developmental milestones, for example, can affect their appraisals of their own child's development and the nature of their interactions with their children. Mothers who are more knowledgeable about child development have more positive interactions with their children than mothers who are less knowledgeable about child development. Because expectations are at least partly shaped by knowledge, the more complete and accurate a mother's knowledge of childrearing and child development is, the more realistic will be her expectations of her children and her parenting. Mothers whose expectations are unrealistic tend to experience greater stress as a result of mismatches between expectations and actual behaviors (Crnic \& Acevedo, 1995), and their interactions with their children may be marked with greater discord and conflict (Teti \& Gelfand, 1991).

Knowledge is a key part of parents' general beliefs systems, which themselves vary across cultures, and so knowledge can be expected to affect parenting practices differently across cultures. For example, mothers in rural Thailand do not believe their infants can see (only 1.7\% believe their babies can see at 1 week, $14.7 \%$ at 1 month), and they normally swaddle infants on their backs in a hammock that allows the baby only a narrow slit view of the ceiling or sky (Kotchabhakdi, Winichagoon, Smitasiri, Dhanamitta, \& Valyasevi, 1987). Gusii and Samoan caregivers believe that it is nonsensical to talk to infants before they are capable of speech (Dixon, Keefer, Tronick, \& Brazelton, 1982; Ochs, 1988; Richman, Miller \& LeVine, 1992). Indeed, culture pervasively influences how mothers view child development (Harkness \& Super, 1995; Palacios, 1990; Sameroff \& Feil, 1985).

We found that education plays a key role in parenting knowledge. Education generally improves parents' perspectives on their lives, enhances their own cognitive and literacy skills, and may engender increased feelings of mastery and competence (Michael, 1972), and education places parents in a position to provide their children with an enriched environment (Menaghan \& Parcel, 1991). Maternal education bears a close relation to individual variation in parenting (Alwin, 1984; Kelly, Sanchez-Hucles, Walker, 1993; Kohn, 1963; Wright \& Wright, 1976) and, through this relation, has an impact on child health (Green, 1970) and development (Hitchcock \& Oliver, 1976; Hoff et al., 2002) even across a wide range of child age and ethnic group membership (e.g., Terrisse, Roberts, Palacio-Quafin, \& MacDonald, 1998). Clearly, these data have implications for parenting education. "Parenting education describes a range of teaching and support programmes which focus on the skills, feelings, and tasks of being a parent" (Einzig, 1996, p. 222), as parent education is an organized effort with clear content, target population, and goals aimed at enhancing or changing parental role performance (Harman \& Brim, 1980). It incorporates experiences that give parents added knowledge and understanding. Parenting educators are concerned, among other topics, with knowledge of childrearing and child development (DeBord, Smith, Mulroy, Tanner, \& Silliman, 1997). Parent education can positively affect the satisfaction and functioning of families by communicating knowledge about child development and parenting that increases understanding as it does in providing alternative models of parenting that widen parents' choices, teaching new skills, and facilitating access to community services (Hammer \& Turner, 1985). 


\section{Acknowledgements}

Maria Lucia Seidl de Moura was supported by grants from Conselho Nacional de Desenvolvimento Científico e Tecnológico (CNPq) and Fundação Carlos Chagas Filho de Amparo à Pesquisa do Estado do Rio de Janeiro (FAPERJ).

The authors wish to thank Cândice D. Silva, Daniel C. Mograbi, Fernando F. Stern, Gabriela B. Altalf, Gabriela S. F. Rangel, Iana Sudo, Juliana Mezzono, Márcia Ângela M. de F. Lima, Paula C. Pontes, and Roberto L. da Silveira for assistance in data collection and Adriana F. P. Ribas for thoughtful comments on earlier drafts of this article.

\section{References}

Alwin, D. F. (1984). Trends in parental socialization values: Detroit, 19581983. American_Journal of Sociology, 90, 359-381.

Azar, S. T. (2002). Parenting and child maltreatment. In M. H. Bornstein (Ed.), Handbook of.parenting (Vol. 4, pp. 361-388). Mahwah, New Jersey: Lawrence Erlbaum Associates.

Benasich, A. A., \& Brooks-Gunn, J. (1996). Maternal attitudes and knowledge of child-rearing: associations with family and child outcomes. Child Development, 67, 1186-1205.

Bornstein, M. H. (1989). Between caretakers and their young: Two modes of interaction and their consequences for cognitive growth. In M. H. Bornstein \& J. S. Bruner (Eds.), Interaction in human development (pp. 197-214). Hillsdale, New Jersey: Lawrence Erlbaum Associates.

Bornstein, M. H. (Ed.). (1991). Cultural approaches to parenting. Hillsdale, New Jersey: Lawrence Erlbaum Associates.

Bornstein, M. H. (2001). Some questions for a science of "culture and parenting” (... but certainly not all). International Society for the Study of Behavioural Development Newsletter, 1, 1-4.

Bornstein, M. H. (Ed.). (2002). Handbook of parenting. Mahwah, New Jersey: Lawrence Erlbaum Associates.

Bornstein, M. H., Hahn, C.-S., Suwalsky, J. T. D., \& Haynes, O. M. (2003). The Hollingshead Four-Factor Index of social status and the Socioeconomic Index of Occupations. In M. H. Bornstein \& R. H. Bradley (Eds.), Socioeconomic status, parenting, and child development (pp. 29-81): Mahwah, New Jersey: Lawrence Erlbaum Associates.

Bornstein, M. H., Seidl de Moura, M. L., \& Ribas, R. de C., Jr. (2002). Measurement of socioeconomic status for parenting and child development research. Unpublished manuscript, National Institute of Child Health and Human Development.

Brislin, R. W. (1980). Translation and content analysis of oral and written material. In H. C. Triandis \& J. W. Berry (Eds.), Handbook of crosscultural psychology (Vol. 1, pp. 389-444). Boston: Allyn \& Bacon.

Brislin, R. W. (1986). The wording and translation of research instruments. In W. J. Lonner \& J. W. Berry (Eds.), Field methods in cross-cultural research (pp. 137-164). Newbury Park, California: Sage.

Bronfenbrenner, U. (1958). Socialization and social class through time and space. In E. E. Maccoby, R. M. Newcomb, \& E. L. Harley (Eds.), Readings in social psychology (pp. 400-425). New York: Holt, Rinehart, and Winston.

Collins, W. A., Maccoby, E. E., Steinberg, L., Hetherington, E. M., \& Bornstein, M. H. (2000). Contemporary research on parenting: The case for nature and nurture. American Psychologist, 55, 218-232.

Conrad, B., Gross, D., Fogg, L., \& Ruchala, P. (1992). Maternal confidence, knowledge, and quality of mother-toddler interactions: A preliminary study. Infant Mental Health Journal, 13, 353-362.
Crnic, K., \& Acevedo, M. (1995). Everyday stresses and parenting. In M. H. Bornstein (Ed.), Handbook of parenting (Vol. 4, pp. 277-297). Mahwah, New Jersey: Lawrence Erlbaum Associates.

DeBord, K., Smith, C., Mulroy, M., Tanner, P., \& Silliman, B. (1997). The emergence of the_parenting profession, National Council for Family Relations. Arlington, VA.

Dichtelmiller, M., Meisels, S. J., Plunkett, J. W., Bozynski, M. A., Claflin, C., \& Mangelsdorf, S. C. (1992) The relationship of parental knowledge to the development of extremely low birth weight infants. Journal of Early Intervention, 16, 210-220.

Dixon, S., Keefer, C., Tronick, E., \& Brazelton, T. B. (1982). Perinatal circumstances and newborn outcome among the Gusii of Kenya: Assessment of risk. Infant Behavior and Development, 5, 11-32.

Eizing, H. (1996). Parenting education and support. In R. Bayne \& I. Horton (Eds.), New directions in counseling (pp. 220-234). Florence, United States: Taylor \& Francis - Routledge.

Field, T. M., Widmayer, S. M., Stringer, S., \& Ignatoff, E. (1980). Teenage, low-class, black mothers and their preterm infants: An intervention and developmental follow-up. Child_Development, 51, 426-436.

Ganzeboom, H. B. G., De Graaf, P. M., \& Treiman, D. J. (1992). A standard international socio-economic index of occupational status. Social Science Research, 21, 1-56.

Ganzeboom, H. B. G., \& Treiman, D. J. (1996). Internationally comparable measures of occupational status for the 1988 international standard classification of occupations. Social_Science Research, 55, 201-239.

Garcia Coll, C. T., \& Pachter, L. M. (2002). Ethnic and minority parenting. In M. H. Bornstein (Ed.), Handbook of parenting (Vol. 4, pp. 1-20). Mahwah, New Jersey: Lawrence Erlbaum Associates.

Goodnow, J. J., Cashmore, J., Cotton, S., \& Knight, R. (1984). Mothers' developmental timetables in two cultural groups. International Journal of Psychology, 19, 193-205

Goodnow, J., \& Collins, W. A. (1990). Development according to parents. The nature, sources, and consequences of parents' ideas. London: Erlbaum.

Green, I. W. (1970). Manual for scoring socioeconomic status for research on health behaviors. U.S. Public Health Reports, 85, 815-827.

Grusec, J. E., \& Goodnow, J. J. (1994). Impact of parental discipline methods on the child's internalization of values: A reconceptualization of current points of view. Developmental_Psychology, 30, 4-19.

Hammer, T. J., \& Turner P. H. (1985). Parenting in contemporary society. Englewood, New Jersey: Prentice Hall.

Harkness, S., \& Super, C. (1995). Parental ethnotheories. In M. H. Bornstein (Ed.), Handbook of parenting (Vol. 2, pp. 211-234). Hillsdale, New Jersey: Erlbaum.

Harman, D., \& Brim, O. G., Jr. (1980). Learning to be parents. Principles, programs and methods. Beverly Hills, California: Sage.

Harwood, R. L., Schoelmerich, A., Ventura-Cook, E., Schulze, P. A., \& Wilson, A. (1996). Culture and class influences on Anglo and Puerto Rican mothers' beliefs regarding long-term socialization goals and child behavior. Child Development, 67, 2446-2461.

Hess, R., Kashiwagi, K., Azuma, J., Price, G. G., \& Dickson, W. (1980). Maternal expectations for early mastery of developmental tasks and cognitive and social competence of preschool children in Japan and the United States. International Journal of Psychology, 15, 259-272.

Hickson, G. B., \& Clayton, E. W. (2002). Parents and their children’s doctors. In M. H. Bornstein (Ed.), Handbook of parenting (Vol. 5, pp. 439-462). Mahwah, New Jersey: Lawrence Erlbaum Associates.

Hitchcock, D. C., \& Oliver, L. I. (1976). Intellectual development and school achievement of youths 12-17 years: Demographic and socioeconomic factors. Vital and Health Statistics, 158, 65.

Hoff, E., Laursen, B., \& Tardif, T. (2002). Socioeconomic status and parenting. In M. H. Bornstein (Ed.), Handbook of parenting (Vol. 2, pp. 231-252). Mahwah, New Jersey: Lawrence Erlbaum Associates. 
Holden, G. W., \& Buck, M. J. (2002). Parental attitudes toward childrearing. In M. H. Bornstein (Ed.), Handbook of parenting (Vol. 3, pp. 537-562). Mahwah, New Jersey: Lawrence Erlbaum Associates.

Hollingshead, A. B. (1975). The four-factor index of social status. Unpublished manuscript, Yale University.

Impicciatore, P., Nannini, S., Pharm, D., Pandolfini, C., \& Bonati, M. (1998). Mothers' knowledge of attitudes toward, and management of fever in preschool children in Italy. Preventive Medicine, 27, 268-273.

Kelly, M. L., Sanchez-Hucles, J., \& Walker, R. (1993). Correlates of disciplinary practices in working- to middle-class African-American mothers. MerrillPalmer Quarterly, 39, 252-264.

Kohn, M. L. (1963). Social class and parent-child relationships: An interpretation. American Journal of Sociology, 68, 471-480.

Kotchabhakdi, N. J., Winichagoon, P., Smitasiri, S., \& Valyasevi, A. (1987). The integration of psychosocial components in nutrition education in northeastern Thai villages. Asia-Pacific_Journal of Public Health, 1, 1625.

MacPhee, D. (1981). Manual for the knowledge of infant development inventory. Unpublished manuscript, University of North Carolina.

Melamed, B. G. (2002). Parenting the ill child. In M. H. Bornstein (Ed.), Handbook of_parenting (Vol. 5, pp. 329-348). Mahwah, New Jersey: Lawrence Erlbaum Associates.

Menaghan, E. G., \& Parcel, T. (1991). Determining children's home environments: The impact of maternal characteristics and current occupational and family conditions. Journal of Marriage and the Family, 53, 417-431.

Michael, L. (1972). Culture and gender roles: There's no unisex in the nursery. Psychology Today, 5, 54-57.

Miller, C. L. (1988). Parent perceptions and attributions of infant vocal behavior and development. First Language, 8, 125-141.

Miller, S. A. (1988). Parents' beliefs about children's cognitive development. Child Development, 59, 259-285.

Murphy, D. A. (1992). Constructing the child: Relations between parents' beliefs and child outcomes. Developmental Review, 12, 199-232.

Ninio, A. (1979). The naive theory of the infant and other maternal attitudes in two groups in Israel. Child Development, 50, 976-980.

Ninio, A. (1988). The effects of cultural background, sex, and parenthood on beliefs about the timetable of cognitive development in infancy. MerrillPalmer Quarterly, 34, 369-388.

Ochs, E. (1988). Culture \& language development. Cambridge: Cambridge University Press.

Pachter, L. M., \& Dworkin, P. H. (1997). Maternal expectations about normal child development in 4 cultural groups. Archives of Pediatrics and Adolescent Medicine, 151, 1144-1150.

Palacios, J. (1990). Parents ideas about the development and education of their children: Answers to some questions. International Journal of Behavioral Development, 13, 137-155.
Parcel, T. L., \& Menaghan, E. G. (1994). Parents' jobs and children's lives. Hawthorne, New York: Aldine De Gruyter.

Parks, P. L., \& Smeriglio, V. L. (1986). Relationships among parenting knowledge, quality of stimulation in the home and infant development. Family Relations, 35, 411-416.

Richman, A. L., Miller, P. M., \& LeVine, R. A. (1992). Cultural \& educational variations in maternal responsiveness. Developmental Psychology, 28(4), 614-621.

Ribas, R. C., Jr., Seidl de Moura, M. L., Soares, I. D., Gomes, A. A. N., \& Bornstein, M. H. (2003). Socioeconomic status in Brazilian psychological research: I. validity, measurement, and application. Estudos de Psicologia, 8(3), 375-383.

Sameroff, A. J., \& Feil, I. A. (1985). Parental concepts of development. In I. E. Sigel (Ed.), Parental belief systems. The psychological consequences for children (pp. 83-105). Hillsdale, New Jersey: Erlbaum.

Sanson, A., \& Rothbart, M. K. (1995). Child temperament and parenting. In M. H. Bornstein (Ed.), Handbook of parenting (Vol. 4, pp. 299-321). Mahwah, New Jersey: Lawrence Erlbaum Associates.

Sigel, I. E., \& McGillicuddy-De Lisi, A. V. (2002). Parent beliefs are cognitions: The dynamic belief systems model. In Marc H. Bornstein (Ed.), Handbook of parenting (Vol. 3, pp. 485-508). Mahwah, New Jersey: Lawrence Erlbaum Associates.

Super, C. M., \& Harkness, S. (1986). The developmental niche: A conceptualization of the interface of child and culture. International Journal of Behavioral Development, 9, 546-569.

Terrisse, B., Roberts, D. S. L., Palacio-Quafin, E., \& MacDonald, B. E. (1998). Effects of parenting practices and socioeconomic status on child development. Swiss Journal of Psychology, 57, 114-123.

Teti, D. M., \& Gelfand, D. M. (1991). Behavioral competence among mothers of infants in the first year: The mediational role of maternal self-efficacy. Child Development, 62, 918-929.

Tirosh, E., Mansour, Y., Jaffe, M., \& Cohen, A. (1998). The differences in health concerns between mothers and health care professionals in a preventive community set up. European Journal of Epidemiology, 14, 253-257.

Treiman, D. J. (1977). Occupational prestige in comparative perspective. New York: Academic Press.

van de Vijver, F. J. R., \& Leung, K. (1997). Methods and data analysis for cross-cultural research. Thousand Oaks, California: Sage.

Wright, J. D., \& Wright, S. R. (1976). Social class and parental values for children: A partial replication and extension of the Kohn thesis. American Sociological Review, 41, 527-537.

Young, K. T. (1991). What parents and experts think about infants. In F. S. Kessel, M. H. Bornstein, \& A. J. Sameroff (Eds.), Contemporary constructions of the child. Hillsdale, New Jersey: Erlbaum.

Rodolfo de Castro Ribas Jr. is a doctoral student and an Assistant Professor at Universidade Federal do Rio de Janeiro.

Maria Lucia Seidl de Moura, doctor in Cognitive Psychology, Fundação Getúlio Vargas, is a Full Professor at Universidade do Estado do Rio de Janeiro.

Marc H. Bornstein is a Senior Investigator in the National Institute of Child Health and Human Development, Bethesda, Maryland, U.S.A.

Correspondence concerning this article should be addressed to Rodolfo de Castro Ribas Jr.; Rua Ferreira Pontes, 286 Apt. 1007A - Andaraí; Rio de Janeiro, RJ; CEP 20541-280 - Brazil. E-mail: rribas@ pobox.com 